\title{
LENIN W ANGLII
}

\section{MARIO TRONTI}

\begin{abstract}
Abstrakt: Lenin w Anglii to słynny tekst Trontiego otwierający pierwszy numer czasopisma Classe operaia, założonego po tym, jak Tronti wraz ze współpracownikami zerwał ze środowiskiem pierwszego operaizmu skupionego wokół Quaderni Rossi. To właśnie w tym tekście Tronti sformułował słynny „kopernikański zwrot w marksizmie”, zgodnie z którym punktem wyjścia analizy rzeczywistości społecznej i historii kapitalizmu powinna być walka klasy robotniczej, a nie prawa rozwoju kapitału. Do zdefiniowania zwrotu popchnęła Trontiego przedstawiona w tekście diagnoza sytuacji włoskiej klasy robotniczej w latach 60 . Kontrowersyjne tezy Trontiego i jego radykalna postawa wpłynęły znacząco na dyskusje prowadzone na radykalnej włoskiej lewicy i na działania wielu aktywistów w latach 60. i 70.
\end{abstract}

Słowa kluczowe: klasa robotnicza, partia robotnicza, marksizm, strategia i taktyka, kopernikański zwrot w marksizmie, gazeta robotnicza. 
Rozpoczyna się nowa epoka walki klas. Robotnicy narzucili ją kapitalistom obiektywna przemoca siły zorganizowanej fabryki. Równowaga władzy wydaje się nie do ruszenia; stosunki sił sa niesprzyjające. A jednak, tam gdzie dominacja kapitału jest najsilniejsza, tam największe jest zagrożenie ze strony robotników. Łatwo tego nie widzieć. Położeniu klasy robotniczej musimy przyglądać się długo i uważnie. Kapitalistyczne społeczeństwo ma swoje prawa rozwoju: wynaleźli je ekonomiści, wprowadzili rządzący, a robotnicy zostali im podporządkowani. Kto jednak odkryje prawa rozwoju klasy robotniczej? Kapitał ma swoja historię i swoich historyków, którzy ją piszą. Kto jednak napisze historię klasy robotniczej? Istniało wiele form politycznej dominacji kapitalistycznego wyzysku. W jaki sposób jednak ma nastać następna forma dyktatury robotników, zorganizowanych jako klasa panująca? Z tym wybuchowym materiałem społecznym musimy pracować cierpliwie, dogłębnie, od wewnątrz.

Także i my wpierw widzieliśmy kapitalistyczny rozwój, a potem dopiero walki robotnicze. To błąd. Należy odwrócić problem, zmienić znak, zacząc od innej zasady: od walki klasy robotniczej ${ }^{1}$. Na poziomie rozwiniętego kapitału społecznego ${ }^{2}$ kapitalistyczny rozwój podporządkowany jest walkom robotniczym; po nich następuje i do nich odnosi się polityczny mechanizm jego wytwarzania. Nie jest to pusta retoryka służąca odzyskaniu pewności siebie. Prawda jest, że koniecznie trzeba dziś oczyścić powietrze z aury porażki robotników, która od dekad pęta to, co narodziło się jako jedyny rewolucyjny ruch, nie tylko

1 Zdanie to stanowi jedno z najlepszych sformułowań tzw. „kopernikańskiej rewolucji w marksizmie”, która stanowi zasadniczy problem teoretyczny opublikowanej w 1966 roku książki Trontiego Operai e capitale [Robotnicy i kapitał] zawierającej jego artykuły publikowane od początku lat 60., w tym również „Lenina w Anglii”. Ideę „rewolucji kopernikańskiej” Tronti przywołuje wprost we wstępie do swojej książki, odnosząc ją do odwrócenia przez Marksa dialektyki Heglowskiej. Ale w idei tej idzie o coś więcej: nie tylko o „postawienie dialektyki z głowy na nogi”, jak wyraził się kiedyś Engels, lecz o sformułowanie idei nauki społecznej zajmującej określona pozycję na gruncie walki klas, a więc świadomie ujmującej badane fenomeny wyłącznie z perspektywy robotniczej. Alberto Toscano podkreśla, że należałoby mówić w tym wypadku raczej o „rewolucji Einsteinowskiej”, rewolucji biorącej za punkt wyjścia teorię względności (Toscano 2009); zresztą we wspomnianym wstępie Tronti sam odwołuje się do Einsteina i teorii względności (Tronti 2006, 9) [wszystkie przypisy pochodzą od tłumacza].

2 Wyrażenie capitale socialmente sviluppato należałoby wprost tłumaczyć jako „kapitał społecznie rozwinięty”, co źle brzmi w języku polskim i nie naprowadza czytelnika na sens, o który chodzi w tekście. W sformułowaniu tym zawarta jest bowiem teza o wychodzeniu stosunku kapitału poza fabrykę i przekształcanie powoli całego pola społecznego zgodnie z logiką kapitału jako relacji społecznej, którą to tezę Tronti sformułował w roku 1962 w eseju „Fabryka i społeczeństwo” (Tronti 2013), a następnie rozwinął w tekście z roku 1963 o oryginalnym tytule „Capitale sociale”, czyli „kapitał społeczny” (w kolejnych wydaniach Operai i capitale tytuł zmieniono na „Il piano del capitale”, a więc „Plan kapitału”). Do idei „kapitału społecznego” wielu operaistów i postoperaistów (m.in. Toni Negri) będzie odwoływało się później, mając na myśli zarówno ujęcie Trontiego, jak i koncepcję wypracowaną wcześniej przez Raniero Panzeriego na bazie interpretacji II tomu Kapitału Marksa. Panzieri potrzebował pojęcia, którym zastapiłby liberalny „,wolny rynek” - „kapitał społeczny” w jego ujęciu (czerpał przy tym inspiracje przede wszystkim od Keynesa) to kapitał zunifikowany i zintegrowany z państwem i instytucjami społecznymi, które służą podtrzymaniu wymiany rynkowej i przepływu kapitału. Z tego względu wyrażenie capitale socialmente sviluppato tłumaczę właśnie jako „rozwinięty kapitał społeczny”. Warto może na końcu podkreślić, że jest to zupełnie inne rozumienie „kapitału społecznego” niż to stojące za tak samo brzmiącymi pojęciami wykorzystywanymi przez Pierre’a Bourdieu czy Roberta D. Putnama. 
w naszej epoce. Konieczność praktyczna nie zawsze jednak wystarcza do podtrzymania tezy naukowej: ta stanąć musi na własnych nogach na historycznym splocie materialnych faktów. Tak więc wszyscy są zobowiązani wiedzieć, że najpóźniej od owego czerwca 1848 roku, po tysiąckroć przeklinanego przez burżuazję, robotnicy wyszli na scenę i więcej jej już nie opuszczali: zgodnie z własną wolą decydowali, raz za razem, o wcieleniu się w różne role aktorów, suflerów, technicznych, sprzątaczy - w oczekiwaniu na moment, by zejść na widownię i zaatakować widzów. W jaką rolę wcielili się dzisiaj, na współczesnej scenie?

W punkcie wyjścia nowego dyskursu mówimy, że na poziomie krajowym i międzynarodowym aktualna, partykularna sytuacja polityczna klasy robotniczej kieruje i narzuca kapitałowi pewien typ rozwoju ${ }^{3}$. Chodzi o to, by w świetle tej zasady rzucić ponownie światło na całą globalną sieć stosunków społecznych. Jest to według nas fundamentalny materialny punkt wyjścia, przez który należy rozumieć rekompozycję światowego rynku jako makroskopijny proces następujący w momencie, w którym rozwój rynku przestał być dławiony przez stalinizm. Łatwo byłoby wytłumaczyć to na gruncie ekonomizmu i pójść dalej, w matematyczny sposób rozważając problem rynków w kapitalistycznej produkcji. Ale robotniczy punkt widzenia szuka wytłumaczenia politycznego. Zjednoczony rynek światowy oznacza dziś kontrolę siły roboczej na poziomie międzynarodowym. Produkcja towarów może by zorganizowana, z trudnościami, także w sferze ograniczonej wymiany. Ruchy klasy robotniczej - nie. Siła robocza rodzi się od razu historycznie homogeniczna na poziomie międzynarodowym i zmusza kapitał - w długim okresie historii - by sam stał się równie homogeniczny. A dzisiaj to właśnie jedność ruchu klasy robotniczej na poziomie światowym zmusza kapitał, by szybko odszukał własna ujednoliconą odpowiedź.

Ale jak możliwe jest sformułowanie tej jedności ruchów klasy robotniczej? Instytucjonalne poziomy ruchu robotniczego wszystko dzielą, kapitalistyczne struktury wszystko jednocza, ale jedynie we własnym, wykluczającym interesie. Aktu politycznej walki nie można poddać empirycznej weryfikacji. Jedynym sposobem na weryfikację tej jedności jest przejście do jej organizowania. Odkryje się wówczas, że nowa forma jedności klasowej jest w całości zawarta w nowych formach walki robotniczej i że jej nowym terenem jest poziom międzynarodowego kapitału społecznego. Na tym poziomie polityczna sytuacja robotników jeszcze nigdy nie była tak klarowna: w każdym momencie historii, w którym koncentrowała się społeczna masa przemysłowej siły roboczej, można było gołym okiem dostrzec te same kolektywne postawy, te same fundamentalne wybory praktyczne, wyjątkowy

\footnotetext{
3 Jest to jeszcze inne sformułowanie „kopernikańskiej rewolucji w marksizmie”. Trontiemu chodzi tutaj o pewną tezę dotyczą logiki walki klas, mianowicie że to nie kapitał jest główną siłą kształtująca rozwój kapitalizmu i mająca inicjatywę w walce klasowej, lecz że są nim robotnicy - to ich walki i próby organizacji determinują odpowiedź kapitału, a przez to też model ekonomicznego i politycznego rozwoju społeczeństw kapitalistycznych.
} 
typ politycznego wzrostu ${ }^{4}$. Programowy brak współpracy, zorganizowana pasywność, polemiczne wyczekiwanie, polityczna odmowa, ciagłość nieustających walk - oto specyficzne historyczne formy, w których uogólnia się dziś walka klasy robotniczej. Formy przejściowe przejściowej sytuacji, kiedy robotnicy znajduja się społecznie poza starymi organizacjami, a jeszcze przed nową organizacją: w rzeczy samej, bez organizacji politycznej, czy to reformistycznej, czy rewolucyjnej. Musimy w pełni pojąć i zrozumieć rezultaty tego okresu bezkrólewia w historii robotniczej: konsekwencje polityczne będą decydujące.

Pierwszą konsekwencją nie przypadkiem okazuje się pewna trudność: jak zebrać materialne ruchy klasy w sytuacji braku odpowiednich poziomów instytucjonalnych, a więc poziomu, na którym normalnie wyraża się świadomość klasy. Dlatego właśnie wymagany jest od nas największy i najbardziej abstrakcyjny wysiłek teoretyczny, ale jednocześnie również jego najbardziej klarowna praktyczna funkcjonalność, która polega na analizie klasy robotniczej niezależnie od ruchu robotniczego. A drugą konsekwencją okazują się sprzeczności i pozorne wattpliwości w ruchach klasy. Jeśli klasa robotnicza posiadałaby rewolucyjna organizację polityczna, to na pewno wskazywałaby ona na instrumentalne wykorzystanie najważniejszego punktu kapitalistycznego reformizmu, gdziekolwiek by się on znajdował. Proces jednoczącej kompozycji kapitału na poziomie międzynarodowym może stać się materialną bazą dla politycznej rekompozycji klasy robotniczej i w tym sensie pozytywnym momentem strategicznym dla rewolucji, pod warunkiem, że będzie towarzyszył rewolucyjnemu wzrostowi nie tylko klasy, lecz także organizacji klasy. Przy braku tego elementu wewnętrzny proces żyje jako funkcja kapitału, taktyczny moment unilateralnej stabilizacji systemu i pozornej integracji w jego wnętrzu klasy robotniczej jako takiej. Historyczna operacja włoskiego kapitalizmu, organiczna zgoda polityczna między katolikami i socjalistami, w fazie demokratycznego rozwoju swojej dyktatury klasowej może nawet sprawić, że ponownie pojawi się klasyczny model procesu rewolucyjnego, jeśli doprowadzi do przywrócenia włoskim robotnikom partii robotniczej skoncentrowanej już na bezpośrednim przeciwstawianiu się systemowi kapitalistycznemu. Bez tej prawowitej restytucji okresowy wyzysk kapitalistyczny stanie się tym bardziej nie do ruszenia, a robotnicy zostaną zmuszeni do szukania innej drogi dla swojej rewolucji. Jeśli jednak jest rzeczywiście prawda, że klasy robotnicze obiektywnie narzucaja kapitałowi konkretne wybory, to prawda jest także, że kapitał włącza potem te wybory do antyrobotniczych funkcji. W tym momencie kapitał jest lepiej zorganizowany niż klasa robotnicza: wybory, które ta narzuca kapitałowi, moga go

\footnotetext{
4 Charakterystyczne dla języka operaistów była używanie do socjologicznego i politycznego opisu aktywności klasy robotniczej tych samych terminów, którymi posługiwała się (kapitalistyczna) teoria ekonomiczna. Stąd przeciwieństwie „rozwoju kapitalistycznego” [sviluppo capitalistico] i „rozwoju politycznego” [sviluppo politico] klasy robotniczej; stąd też trochę dziwny zwrot crescita politica, który tłumaczę właśnie jako „wzrost polityczny”, gdyż odpowiednio crescita economica tłumaczylibyśmy jako „wzrost ekonomiczny”.
} 
jedynie wzmocnić. Dlatego bezpośrednim interesem klasy robotniczej jest przeciwstawić się tym wyborom.

Strategiczna wizja klasy robotniczej jest dzisiaj tak wyraźna, że można dojść do wniosku, iż dopiero teraz zaczyna się etap jej pięknej dojrzałości. Odkryła ona - po raz pierwszy lub kolejny - prawdziwy sekret, który skaże na śmierć jej klasowego wroga: polityczną zdolność do umiejętnego narzucania kapitałowi reformizmu i do brutalnego wykorzystania go dla celów robotniczej rewolucji. Ale obecna pozycja taktyczna klasy robotniczej - klasy nieposiadającej organizacji klasowej - jest i musi z konieczności być mniej klarowna i, można by nawet rzec, nieco bardziej ambiwalentna. Robotnicy wciąż są zmuszani do wykorzystywania sprzeczności, które prowadzą kapitalistyczny reformizm do kryzysu, do intensyfikowania elementów hamujących jego proces rozwoju. Wiedzą bowiem, czuja, że zielone światło dla reformistycznych operacji kapitału przy nieobecności politycznej organizacji klasy robotniczej oznacza zamknięcie na długi czas całego procesu rewolucyjnego - podczas gdy przy obecności takiej organizacji byłoby jego bezpośrednim otwarciem. Tak więc oba reformizmy, reformizm kapitału i reformizm ruchu robotniczego, zdecydowanie powinny się spotkać - lecz z bezpośredniej inicjatywy robotników; kiedy inicjatywa, tak jak ma to miejsce dzisiaj, znajduje się w całości po stronie kapitału, bezpośrednim interesem robotników jest utrzymywać je rozdzielone. Taktycznie słuszne jest również to, by reformizmy te spotkały się, gdy klasa robotnicza ma już nie tylko doświadczenie walki, ale walki rewolucyjnej, a w jej ramach doświadczenie modeli alternatywnej organizacji. Tak więc historyczne spotkanie reformizmu kapitalistycznego $z$ reformizmem ruchu robotniczego sygnalizuje prawdziwe otwarcie procesu rewolucyjnego. Dzisiejsza sytuacja nie ma z tym jednak nic wspólnego: przygotowuje ją i poprzedza. Stąd ogólne poparcie ze strony robotników dla rozwoju kapitału i taktyczna opozycja wobec różnych wersji tego rozwoju. Dziś taktyka i strategia są w klasie robotniczej sprzeczne.

Sprzeczne sa zatem polityczny moment taktyki i teoretyczny moment strategii przeciwstawiaja się sobie w skomplikowanym i wysoce zapośredniczonym związku między rewolucyjną organizacja i robotniczą nauka. Na poziomie teoretycznym punkt widzenia robotników nie musi dziś posiadać granic, nie musi stawiać barier, musi za to skakać naprzód, przekraczając i negując wszelkie dowody i fakty, których nieustannie domaga się intelektualne tchórzostwo drobnej burżuazji. Dla myśli robotniczej powrócił moment odkrycia. Czas systematyzacji, powtórzenia, wulgarności dostosowanej do systematycznego dyskursu zdecydowanie się skończył: to, do czego na nowo, po raz kolejny, trzeba wrócić, to żelazna logika stronniczości [logica di parte], odwaga poświęcenia się sobie i indyferentna ironia w stosunku do innych. Należy unikać błędu mylenia tego wszystkiego z programem politycznym; należy wystrzegać się pokusy walki i bezpośredniego przenoszenia tego teoretycznego nastawienia do walki politycznej, walki prowadzonej na bazie dokładnych 
danych, które w niektórych przypadkach słusznie przeczą formie teoretycznych ustaleń. Praktyczna odpowiedź na praktyczne problemy, na bezpośrednią walkę, bezpośrednia organizację, bezpośrednią interwencję w sytuację klasy, wszystko to wpierw mierzy się według obiektywnych potrzeb rozwoju ruchu i dopiero w kolejnej instancji weryfikuje zgodnie z ogólną linią, która podmiotowo narzuca ją wrogowi klasowemu.

Ale rozdział teorii i praktyki jest jedynie konsekwencją sprzeczności między strategia i taktyką. Jedna i druga szukają swojej materialnej bazy w trwającym wciąz, powolnym procesie, który wpierw oddziela, a później przeciwstawia sobie klasę i historyczne organizacje tej klasy, „klasę robotniczą” i „ruch robotniczy”. Co konkretnie mówi ten dyskurs i co chce osiagnąć? Warto od razu wprost powiedzieć, że celem do osiagnięcia jest głęboka rekompozycja politycznie poprawnego związku między dwoma ruchami: nie będzie się poddawało teoretycznej obróbce żadnej postaci ich podziału, nie będzie się praktykowało żadnej postaci przeciwstawiania ich sobie, w jakimkolwiek punkcie, nawet okresowo. Jeśli jedna z części ruchu odzyska życie rewolucji przeznaczone dla własnej klasy, proces ponownego zjednoczenia będzie niezwykle szybki, prosty, bezpośredni i pewny; w przeciwnym wypadku, ten sam proces będzie równie pewny, lecz mniej oczywisty, mniej zdecydowany, dłuższy i bardziej dramatyczny. Łatwo można dojrzeć efekty zafałszowania działań starych organizacji w stosunku do nowych walk robotniczych. Trudniej już pojąć ciagła, świadomą instrumentalizację przez robotników tego, co nawet kapitaliście jawi się jako ruch zorganizowanych robotników.

W szczególności: klasa robotnicza oddała w ręce swoich tradycyjnych organizacji wszystkie problemy taktyki, by zarezerwować dla siebie autonomiczną wizję strategiczną, wolną od przeszkód i pozbawiona kompromisów. Ponownie z tym samym tymczasowym rezultatem: rewolucyjna strategia i reformistyczna taktyka. Nawet jeśli, jak zwykle, wydaje się, że jest dokładnie na odwrót, że mianowicie robotnicy pozostają obecnie w zgodzie z systemem i tylko czasami dochodzi do jakiegoś tarcia - jest to „burżuazyjny” pozór kapitalistycznego stosunku społecznego. W rzeczywistości nawet związkowe potyczki mają dla robotników polityczne znaczenie akademickich ćwiczeń w ich walce o władzę: i jako takie właśnie robotnicy je traktuja, wykorzystują, a wykorzystawszy w ten sposób - oddaja je szefowi. Prawdą jest, że na poziomie praktyki robotników żywa jest wciąż klasyczna teza marksistowska: związkowi moment taktyczny, partii moment strategiczny. Właśnie z tego powodu, jeśli istnieje związek między klasą robotniczą i związkiem, to związek ten nie istnieje już między klasą robotniczą i partią. Stąd wyzwolenie strategicznej perspektywy bezpośrednich zadań organizacyjnych, przejściowy rozłam między walką klas i organizacją klasy, między momentem ciągłej walki i prowizorycznymi formami organizacji, konsekwencja historycznego upadku reformizmu socjalistycznego i przesłanka politycznego rozwoju rewolucji robotniczej. 
To właśnie na wnętrzu tego mechanizmu rozwoju - już nie kapitalizmu, lecz rewolucji - należy wymusić skupienie uwagi teoretycznych badań i praktycznej pracy. Modeli nie ma. Historia przeszłych doświadczeń ma służyć wyzwoleniu się od nich. Musimy zawierzyć wszystko nowemu typowi naukowej prognozy. Wiemy, że cały proces rozwoju materialnie urzeczywistnia się na nowym szczeblu robotniczych walk. Punktem wyjścia jest zatem odkrycie pewnych form walk robotników prowokujących pewien typ kapitalistycznego rozwoju, który podąża w kierunku rewolucji. Kolejnym krokiem powinna być artykulacja na bazie tych doświadczeń subiektywnie wybieranych, newralgicznych punktów, w których można uderzyć w kapitalistyczny stosunek produkcji. I na tej bazie, podejmując ciagle to nowe próby, postawić ponownie problem: jak w sposób ciagły odnosić nową organizację do tych nowych walk. Być może odkryje się dzięki temu, że „cuda organizacji” już się osiagnęło i że osiaga się je zawsze w ramach tych cudownych walk klasy robotniczej, których nikt nie zna, których nikt nie chce znać, które jednak same z siebie tworzyły i wciąż tworzą rewolucyjną historię wszystkich rewolucji wszystkich ludów kolonialnych razem wziętych.

By ta praca praktyczna, artykułowana w fabryce, funkcjonowała na terenie społecznego stosunku produkcji, musi być nieustannie oceniana i zapośredniczana na poziomie politycznym, który ją uogólnia. To w ramach tego poziomu politycznego nowego typu należy badać i organizować nową formę gazety robotniczej $j^{5}$ - taką, która ma nie

5 „Lenin w Anglii” był tekstem otwierającym pierwszy numer pisma Classe operaia założonego w efekcie zerwania Trontiego i jego współpracowników (m.in. Romano Alquatiego, Toniego Negriego, Massimo Cacciarego) z wydawanym w latach 1961-1966 pismem Quaderni rossi prowadzonym przez „heretyków na lewicy” we Włoszech (przede wszystkim przez Raniero Panzierego). Zerwanie to określa się często jako narodziny „drugiego operaizmu”, rezerwując określenie „operaizm” przede wszystkim dla okresu wspólnej pracy Panzierego, Trontiego i ich współpracowników i założenia Quaderni rossi. Czasami zaś odwrotnie, określenie „operaizm” stosuje się wyłącznie do idei tworzonych przez środowisko Trontiego po zerwaniu z Panzierim. Niezależnie od kwestii interpretacyjnych wiadome jest, że bezpośrednim powodem tego zerwania, które nastapiło w roku 1963, były wydarzenia z lipca 1962 roku na Piazza Statuto w Turynie. Między 7 a 9 lipca plac był miejscem strajku robotników przemysłu metalowego i mechanicznego (przede wszystkim pracowników Fiata), który został przerwany przez niektóre związki decydujące się podpisać oddzielne, ograniczone porozumienia z pracodawcami. Efektem tych porozumień była eskalacja strajku i zdobycie przez protestujących robotników siedziby Włoskiej Unii Pracy (UIL). Od wydarzeń tych odcięło się m.in. kierownictwo Włoskiej Partii Komunistycznej (mimo że wielu jej młodych działaczy zostało aresztowanych jako uczestnicy protestów). Dla niektórych osób tworzaçych wówczas środowisko Quaderni rossi postawa zarówno partii komunistycznej, jak i związków zawodowych były nie do przyjęcia i doprowadziła do zradykalizowania się ich krytycznego stosunku wobec istniejących form organizacji robotniczych. Krótko podsumowuje to Zbigniew Marcin Kowalewski: „Podczas strajku środowisko Quaderni rossi wystapiło z inicjatywą i pod presją tych, którzy w jego łonie parli do interwencji politycznej w walkach robotniczych, jako grupa polityczna. Wydało mianowicie odezwę, w której głosiło, że strajk ten to wielka okazja, aby poczynić »krok naprzód w sferze organizacji klasy«, tworząc na wszystkich wydziałach i we wszystkich zakładach Fiata organizacje, które "potrafiłyby stawić czoło wyzyskowi, samowoli pracodawcy i jego służalców«. Akcja ta spotkała się z bardzo negatywną reakcją kierownictwa FIOM [federacja pracowników przemysłu metalowego - przyp. MR], w tym również działaczy, którzy dotychczas sprzyjali operaizmowi. Teraz zerwali z Quaderni rossi i z samym Panzierim. Było to dla niego ciężkim ciosem, natomiast dla części środowiska stało się wodą na młyn antyzwiązkowych postaw i czynnikiem je radykalizującym" (Kowalewski 2015, 174-175). Classe operaia została założona w celu teoretycznego opracowania tego, co Tronti uważał wówczas za najważniejszy problem polityczny, mianowicie rozejścia się dążeń, pragnień i form organizacji pracowników oraz istniejących struktur 
tylko powtarzać i odzwierciedlać wszystkie partykularne doświadczenia, lecz właśnie skupiać je w jednym ogólnym dyskursie politycznym. Gazeta jest w tym sensie punktem kontroli, albo lepiej: samokontroli strategicznej zasadności pojedynczych doświadczeń walki. Dyskurs polityczny jest z kolei tym, co ma weryfikować poprawność partykularnych doświadczeń, a nie vice versa, ponieważ dyskurs polityczny jest, w tym ujęciu, totalnym punktem widzenia klasy, a tym samym prawdziwym materialnym faktem i samym realnym procesem. Latwo zobaczyć, jak oddalamy się w ten sposób od obecnej w leninizmie koncepcji gazety robotniczej, zgodnie z którą miała być ona kolektywnym organizatorem na bazie lub w oczekiwaniu bolszewickiej organizacji klasy i partii. Cele te sa dla nas na aktualnym etapie walki klas niedorzeczne. Obecnie potrzebujemy raczej wyjść od odkrycia politycznej organizacji, jednak nie progresywnej awangardy, lecz całej tej zwartej społecznej masy, która w okresie swojej historycznej dojrzałości stała się klasą robotniczą, a więc jedyną rewolucyjną siłą kontrolującą obecny porządek, straszliwą i przerażającą.

Wszystko to wiemy. A przed nami wiedział to Lenin. A przed Leninem Marks, dzięki prawdziwie ludzkiemu doświadczeniu, odkrył, że najtrudniejsze jest przejście do organizowania. Ciągłość walki jest prosta: robotnicy potrzebuja jedynie samych siebie i szefa nad nimi. Ale ciagłość organizacji jest rzeczą rzadką i skomplikowaną: kiedy tylko zinstytucjonalizuje się ją w jakiejś formie, natychmiast zostanie wykorzystana przez kapitalizm lub przez ruch robotniczy w imieniu kapitalizmu. Stąd gwałtowność, z którą robotnicy pasywnie odrzucają formy organizacji, które właśnie wywalczyli. A wraz z nieustająca walką na poziomie fabryki w ciagle to nowych formach, które jedynie intelektualna fantazja produktywnej pracy jest w stanie odkrywać, wykraczaja poza pusty biurokratyzm ogólnej organizacji politycznej. Jeśli bezpośrednia organizacja polityczna robotników nie stanie się ogólną, nie otworzy się proces rewolucyjny: robotnicy są tego świadomi i dlatego nie widzicie ich dzisiaj chętnych do śpiewania demokratycznych litanii rewolucji w kościołach partii. Rzeczywistość klasy robotniczej związana jest w sposób definitywny z imieniem Marksa. Konieczność jej organizacji politycznej jest w równie definitywny sposób związana z imieniem Lenina. Strategia leninizmu mistrzowskim posunięciem przyniosła Marksa do Petersburga: jedynie punkt widzenia robotników był w stanie zdobyć się na podobną zuchwałość rewolucyjną. Spróbujmy pójść odwrotną drogą, lecz z tym samym naukowym duchem przygody politycznego odkrycia. Lenin w Anglii to badanie nowej marksistowskiej praktyki partii robotniczej: tematy walki i organizacji na najwyższym poziomie politycznego rozwoju klasy robotniczej. Na tym poziomie warto przekonać Marksa, by prześledził „tajemniczy skręt na prostej linii Lenina”.

Styczeń 1964

związkowych i partyjnych. Celem był „problem organizacji politycznej klasy robotniczej i teoretycznopraktyczne działania w celu jej wprowadzenia” (z pierwszego numeru Classe operaia). 
Przetoziyt Mikotaj Ratajczak 


\section{Wykaz literatury}

Kowalewski, Zbigniew Marcin..2015., „Rozłam w operaizmie w świetle dynamiki włoskiego ruchu robotniczego w »czerwonym dziesięcioleciu«1969-1980”, Praktyka Teoretyczna 1(15): 162-214.

Toscano. Alberto 2009. „Chronicles of Insurection: Tronti, Negri and the Subject of Antagonism". Cosmos and History: The Journal of Natural and Social Philosophy, 5/1.

Tronti, Mario.2013. „Fabryka i społeczeństwo”, tłum. Sławomir Królak. . http://www.praktykateoretyczna.pl/mario-tronti-fabryka-i-spoleczenstwo/.

Tronti, Mario. 2006. Operai e capitale. Roma: DeriveApprodi. 
Mario Tronti - jeden z intelektualnych liderów włoskiego operaizmu w latach 60., współzałożyciel czasopisma „Quaderni Rossi”, a następnie redaktor naczelny „Classe operaia”, obecnie senator z ramienia Partii Demokratycznej. Pracował jako wykładowca filozofii moralnej i filozofii politycznej na Universita degli studi w Sienie. Autor m.in.: Con le spalle al future (1992); ostatnio wznowiono jego słynną książkę Operai e Capitale (2006).

CYTOWANIE: Tronti, Mario. 2016. Lenin w Anglii. Praktyka Teoretyczna 2 (20). 183-193.

DOI: $10.14746 /$ prt.2016.2.6 